\title{
IMPACT OF BLOOD PRESSURE COMPONENTS ON LEFT VENTRICULAR HYPERTROPHY REMODELING
}

\author{
Juraj Kunišek ${ }^{1}$ and Leon Kunišek ${ }^{2}$ \\ ${ }^{1}$ Department of Internal Medicine, Crikvenica Thalassotherapia, Special Hospital for Medical Rehabilitation, \\ Crikvenica, Croatia; ${ }^{2}$ Rijeka University Hospital Centre, Department of Cardiac Surgery, Rijeka, Croatia
}

\begin{abstract}
SUMMARY - According to present findings, the impact of particular arterial pressure components on the occurrence of left ventricular hypertrophy (LVH) differs. We sought to determine which individual component of arterial pressure has the greatest impact on the $\mathrm{LVH}$ geometric pattern/degree. The study included 192 patients (87 men), aged 43-80 (median 68) years with hypertension and LVH. Patients were classified into three groups according to type of hypertrophy (concentric, eccentric and asymmetric) and into three subgroups according to the degree of hypertrophy (mild, moderate and severe). All patients had their blood pressure measured, and they underwent electrocardiography and echocardiography. Antihypertensive drugs and the duration of previous treatments were taken into consideration. Pulse pressure was significantly higher in patients with concentric LVH than in those with eccentric and asymmetric LVH $(\mathrm{p}=0.029)$, the values of which did not differ statistically. It rose with LVH degree (not significantly, $\mathrm{p}=0.217$ ). There were no significant differences in systolic pressure among study groups $(\mathrm{p}=0.177)$. We concluded that pulse pressure had the greatest impact on the left ventricular geometry, particularly of the concentric type.
\end{abstract}

Key words: Hypertrophy, left ventricular; Blood pressure; Hypertension; Electrocardiography; Echocardiography

\section{Introduction}

In hypertensive patients, left ventricular hypertrophy $(\mathrm{LVH})$ is a known risk factor for developing heart arrhythmia. According to present findings, the impact of particular arterial pressure components on the occurrence of LVH differs. Pulse pressure as an indicator of stiffness of great arteries has been emphasized as important in predicting cardiovascular risks ${ }^{1,2}$. Several studies completed over the last few years have demonstrated the association between high pulse pressure and damage to target organs such as the carotids, kidneys, and heart ${ }^{3-5}$. All studies investigating the association between pulse pressure and left ventricular mass

Correspondence to: Juraj Kunišek, $M D, P h D$, Crikvenica Thalassotherapia, Special Hospital for Medical Rehabilitation, Gajevo šetalište 21, HR-51260 Crikvenica, Croatia

E-mail: juraj_kunisek@net.hr

Received June 9, 2016, accepted May 9, 2017
(LVM) have shown positive correlation between these two variables. From the pathophysiological perspective, it is important to understand whether the main determinant of higher LVM is a higher pulsatile load, expressed through pulse pressure, or a permanent load increase ${ }^{6,7}$.

It would seem that LVM in hypertensive patients is more closely associated with the peripheral pulse pressure and hemodynamic pulsatile load than with the mean arterial pressure and permanent $\operatorname{load}^{8}$. It is known that pulse pressure affects the occurrence of $\mathrm{LVH}$ but little is known of the type of LVH that is most affected. Few studies investigated which component of arterial pressure has the greatest impact on the formation of LVH types. Some authors found that even after a year of antihypertensive therapy, a high proportion (74\%) of hypertensives of African ancestry retained residual left ventricular structural changes (predominant concentric LVH), an effect that was 
associated with 24-hour pulse pressure, but not with systolic or diastolic blood pressure or clinical blood pressure ${ }^{9}$. Another finding suggests that aortic stiffness and greater early pulsatile hemodynamic load affect left ventricular concentric remodeling in a sex-specific manner (in women but not in men) ${ }^{10}$.

The effect of pulse pressure on the formation of a certain LVH type requires further research, particularly in relation to systolic blood pressure. In order to better understand whether the main determinant of the type of LVH is a higher pulsatile load or permanent load increase we tried to solve the dilemma. The aim of this study was to determine which of the components of arterial pressure (systolic, diastolic, mean or pulse pressure) has the greatest impact on the formation of each individual LVH pattern/degree.

\section{Patients and Methods}

The research was approved by the Ethics Committee of School of Medicine, University of Rijeka, registration number: Class 003-07/98-01/07, N 2170-2404-4-98-01. Upon previous patient written consent and approval of the School of Medicine Ethics Committee, patients were included in the study. The study was conformed to the principles outlined in the Declaration of Helsinki.

\section{Patients}

After applying strict exclusion criteria, at the outpatient department of cardiology we selected $192 \mathrm{pa}^{-}$ tients (87 men and 105 women, aged 43 to 80 years) with essential hypertension and confirmed diagnosis of LVH by echocardiography. Inclusion criteria were only essential hypertension and LVH confirmed by echocardiography. Hypertensive patients were those with blood pressure $\geq 140 / 90 \mathrm{~mm} \mathrm{Hg}$, measured on six or more occasions by mercury sphygmomanometer, according to the guidelines of the European Society of Hypertension and the European Society of Cardiolo$\mathrm{gy}^{11}$. Patients were previously instructed how to measure their pressure at home (three measurements per occasion, 2 min apart). Blood pressure and heart rate measured six or more times a day by the patient, general practitioner and specialist were used to calculate the mean arterial and pulse pressure. Exclusion criteria included patients with congestive heart failure, known coronary disease (angina pectoris, previous myocardial infarction, percutaneous coronary interventions), cardiac surgery, valvular diseases, other cardiac diseases (hypertrophic obstructive cardiomyopathy), diabetes mellitus, alcoholism, mental disorders, excessive use of non-antihypertensive drugs (psychiatric and rheumatology medications), malignant or accelerated hypertension, and a history of stroke in the previous six months. Patients with cancer, anemia, cardiopulmonary diseases and glomerular filtration rate $<60 \mathrm{~mL} /$ $\mathrm{min} / 1.73 \mathrm{~m}^{2}$ were also excluded from the study.

\section{Study variables}

Study variables were age, sex, systolic and diastolic pressure, mean pressure, pulse pressure, body mass index and left ventricular mass, left ventricular mass index (LVMI) adjusted for body surface area, LVM adjusted for height ${ }^{2.7}\left(\mathrm{LVM} / \mathrm{ht}^{2.7}\right)$, left ventricular geometry, and LVH degree. The type and duration of antihypertensive therapy received by the patients before entering the study were recorded to analyze the possible effects on the outcome. Pulse pressure was calculated as difference between systolic and diastolic blood pressure. Mean pressure was calculated as diastolic pressure + pulse pressure/3.

\section{Blood tests}

Blood tests included serum lipids, glucose, urea, creatinine, potassium and sodium before food intake. Red blood count (erythrocytes, hemoglobin, hematocrit) and iron were determined to exclude anemia.

\section{Echocardiography and electrocardiography}

Patients were divided into the following three main groups with regard to LVH type: concentric (relative wall thickness $>0.45$ and interventricular septum/left ventricular posterior wall, IVS/LVPW <1.3), eccentric (left ventricular diameter in systoles $>32$ and relative wall thickness $<0.45$ ) and asymmetric (IVS/LVPW $>1.3$ ), as in a previous study ${ }^{12}$.

Relative wall thickness was measured at end-diastole as the ratio of twice the thickness of left ventricular PW/LVIDd (left ventricular internal diastolic diameter, LVIDd ${ }^{13}$. Each group was further divided into subgroups according to the degree of $\mathrm{LVH}$, as follows: mild (IVS or LVPW 11-12 mm), moderate (IVS or LVPW 13-14 mm) and severe (IVS or LVPW $\geq 15 \mathrm{~mm}$ ) for both sexes. 
All patients underwent 12-lead electrocardiogram and $\mathrm{M}$-mode two-dimensional and Doppler echocardiographic examination. In order to determine $\mathrm{LVH}$, two electrocardiogram criteria were applied, i.e. the Sokolow-Lyon and the left ventricular strain criterion (>0.1 mV ST segment depression with asymmetric T wave inversion in leads V2 to V6 and either lateral or inferior peripheral leads) ${ }^{14}$. A qualified operator performed electrocardiogram interpretation manually.

Echocardiographic measurements were performed and interpreted by three cardiologists working independently, unaware of the hypothesis of the study. M-mode imaging was performed on a $15 \mathrm{~cm}$ wide photosensitive paper, with a velocity of $50 \mathrm{~mm} / \mathrm{s}$, on Toshiba Corevision Pro QA apparatus, with a $2.5 \mathrm{MHz} 16 \mathrm{~mm}$ probe, compliant with the guidelines ${ }^{15}$. LVM was divided by body surface to calculate LVMI. LVMI was calculated according to the Devereux and Reichek formula:

LVMI $=\left(1.04 x\left[\left(I V S+L V P W+L^{2} I D d\right)^{3}-L^{2} I D d^{3}\right]-\right.$ -13.6)/body surface area $)^{16}$. LVH was defined as LVMI greater than $134 \mathrm{~g} / \mathrm{m}^{2}$ for men and greater than 110 $\mathrm{g} / \mathrm{m}^{2}$ for women ${ }^{17}$. LVM $/ \mathrm{ht}^{2.7}>51 \mathrm{~g} / \mathrm{m}^{2.7}$ was defined as $\mathrm{LVH}^{18}$.

We also searched for correlation between systolic blood pressure (SBP), diastolic blood pressure (DBP), mean pressure and pulse pressure on one hand, and the LVH type on the other. All data were classified according to the LVH degree.

\section{Statistical data analysis}

The data collected were statistically evaluated using the STATISTICA, version 8.0. (StatSoft, Inc., Tulsa, OK, USA) data analysis software. Continuous variables were presented by mean, standard deviation and range, and counting variables by frequency or percentage. Parametric tests (t-test or ANOVA test) were used for between-group comparisons of continuous variables. The frequencies were analyzed by the Yates corrected Pearson $\chi^{2}$-test. Coefficient of correlation ( $r$ ) and its statistical significance $(\mathrm{p}<0.05$, statistically significant) was determined. Correlation was considered non-existent (trivial, very weak) at $\mathrm{r}<0.20$, weak at $0.20<\mathrm{r}<0.40$, good at $0.40<\mathrm{r}<0.70$, and very strong at $0.71<\mathrm{r}<0.99$. The level of statistical significance was set at 0.05 in all analyses.

Sample size was estimated by calculation, with input parameters of $\mathrm{p}$-level at 0.05 , effect size of 0.35 and power of 0.80 .
Table 1. Clinical and biochemical patient characteristics and pressures

\begin{tabular}{|c|c|c|}
\hline $\begin{array}{l}\text { Total }(\mathrm{N}) \\
=192 \text { patients }\end{array}$ & M 87 (45.3\%) & F $105(54.7 \%)$ \\
\hline Parameter & Mean \pm SD & Range \\
\hline Age (yrs) & $69 \pm 8$ & $43-80$ \\
\hline $\begin{array}{l}\text { Body mass index } \\
\left(\mathrm{kg} / \mathrm{m}^{2}\right)\end{array}$ & $28.2 \pm 4.0$ & $20.5-46$ \\
\hline $\begin{array}{l}\text { Duration of } \\
\text { hypertension (yrs) }\end{array}$ & $17 \pm 7$ & $1-41$ \\
\hline $\begin{array}{l}\text { Systolic blood } \\
\text { pressure }(\mathrm{mm} \mathrm{Hg})\end{array}$ & $182 \pm 22$ & $130-220$ \\
\hline $\begin{array}{l}\text { Diastolic blood } \\
\text { pressure }(\mathrm{mm} \mathrm{Hg})\end{array}$ & $105 \pm 11$ & $70-121$ \\
\hline $\begin{array}{l}\text { Mean arterial pressure } \\
(\mathrm{mm} \mathrm{Hg})\end{array}$ & $133 \pm 12$ & $105-177$ \\
\hline $\begin{array}{l}\text { Pulse pressure } \\
(\mathrm{mm} \mathrm{Hg})\end{array}$ & $82 \pm 18$ & $42-135$ \\
\hline Frequency beats (min) & $79 \pm 11$ & $52-120$ \\
\hline $\begin{array}{l}\text { Elevated cholesterol } \\
(>5 \mathrm{mmol} / \mathrm{L})(\%)\end{array}$ & \multicolumn{2}{|l|}{80.4} \\
\hline $\begin{array}{l}\text { Elevated triglycerides } \\
(>1.7 \mathrm{mmol} / \mathrm{L})(\%)\end{array}$ & \multicolumn{2}{|l|}{70.4} \\
\hline $\begin{array}{l}\text { Elevated urea } \\
(>8 \mathrm{mmol} / \mathrm{L})(\%)\end{array}$ & \multicolumn{2}{|l|}{67.4} \\
\hline $\begin{array}{l}\text { Elevated creatinine } \\
(>140 \mu \mathrm{mol} / \mathrm{L})(\%)\end{array}$ & \multicolumn{2}{|l|}{4.9} \\
\hline Smokers (\%) & \multicolumn{2}{|l|}{18.8} \\
\hline $\begin{array}{l}\text { Physically inactive (\%) } \\
\text { Obese (\%) }\end{array}$ & \multicolumn{2}{|l|}{$\begin{array}{l}78.8 \\
26 \mathrm{M}, 38 \mathrm{~F}\end{array}$} \\
\hline
\end{tabular}

$\mathrm{M}=$ male $; \mathrm{F}=$ female

\section{Results}

The sample consisted of 192 patients, 87 (45.3\%) male and 105 (54.7\%) female, mean age 65 years. We determined demographic and anthropometric attributes of the patients, as well as data on the duration of hypertension (Table 1). Elderly patients were obese with long-lasting hypertension of average duration of over 15 years. On average, they suffered from severe hypertension and high pulse pressure. Echocardiographic data on the subjects are presented in Table 2.

\section{Relationship between pressures and left ventricular hypertrophy}

Systolic blood pressure. No difference was found in systolic pressure according to LVH type (Table 3). Sys- 
Table 2. Echocardiographic data of study patients

\begin{tabular}{|c|c|c|c|c|c|}
\hline & \multirow[b]{3}{*}{$\mathrm{N}$} & \multirow{2}{*}{ Total } & \multicolumn{2}{|c|}{ Sex } & \multirow{3}{*}{ p } \\
\hline & & & \multicolumn{2}{|c|}{$\mathrm{F}$} & \\
\hline & & 192 & 87 & 105 & \\
\hline LVIDd (cm) & Mean \pm SD & $5.16 \pm 0.55$ & $5.46 \pm 0.57$ & $4.94 \pm 0.47$ & $<0.001$ \\
\hline LVISd (cm) & Mean \pm SD & $3.54 \pm 0.57$ & $3.80 \pm 0.58$ & $3.36 \pm 0.48$ & $<0.001$ \\
\hline IVS (cm) & Mean \pm SD & $1.33 \pm 0.12$ & $1.34 \pm 0.11$ & $1.32 \pm 0.15$ & 0.721 \\
\hline LVPW (cm) & Mean \pm SD & $1.26 \pm 0.10$ & $1.27 \pm 0.10$ & $1.25 \pm 0.11$ & 0.264 \\
\hline $\mathrm{LA}(\mathrm{cm})$ & Mean \pm SD & $3.97 \pm 0.48$ & $4.10 \pm 0.46$ & $3.89 \pm 0.49$ & 0.005 \\
\hline $\mathrm{RV}(\mathrm{cm})$ & Mean \pm SD & $2.38 \pm 0.42$ & $2.41 \pm 0.49$ & $2.35 \pm 0.38$ & 0.401 \\
\hline Aortic root $(\mathrm{cm})$ & Mean \pm SD & $3.34 \pm 0.42$ & $3.58 \pm 0.44$ & $3.15 \pm 0.29$ & $<0.001$ \\
\hline $\mathrm{EF}(\%)$ & Mean \pm SD & $60.7 \pm 7.2$ & $60.3 \pm 6.5$ & $60.9 \pm 7.6$ & 0.526 \\
\hline FS (\%) & Mean \pm SD & $31.8 \pm 8.5$ & $32.8 \pm 10.6$ & $30.9 \pm 4.4$ & 0.480 \\
\hline LVM (g) & Mean \pm SD & $326.89 \pm 74.79$ & $357.11 \pm 79.57$ & $303.31 \pm 61.46$ & 0.001 \\
\hline $\mathrm{LVM} / \mathrm{ht}^{2.7}\left(\mathrm{~g} / \mathrm{m}^{2.7}\right)$ & Mean \pm SD & $81.32 \pm 1.89$ & $79.04 \pm 2.31$ & $84.18 \pm 1.79$ & $<0.001$ \\
\hline $\operatorname{LVMI}\left(\mathrm{g} / \mathrm{m}^{2}\right)$ & Mean \pm SD & $173.98 \pm 34.96$ & $178.12 \pm 35.92$ & $170.84 \pm 34.76$ & 0.223 \\
\hline
\end{tabular}

$\mathrm{M}=$ male $; \mathrm{F}=$ female $\mathrm{EF}=$ ejection fraction; $\mathrm{FS}=$ fractional shortening; $\mathrm{IVS}=$ interventricular septum; $\mathrm{LA}=$ left atrium; LVIDd = left ventricular internal diastolic diameter; LVISd = left ventricular internal systolic diameter; LVM $=$ left ventricular mass; LVM/ht ${ }^{2.7}=\mathrm{LVM}$ adjusted for height ${ }^{2.7} ; \mathrm{LVMI}=$ left ventricular mass index; $\mathrm{LVPW}=$ left ventricular posterior wall; $\mathrm{RV}=$ right ventricle

Table 3. Systolic blood pressure according to type and degree of LVH

\begin{tabular}{|c|c|c|c|c|c|}
\hline \multirow[b]{2}{*}{ LVH degree } & \multicolumn{3}{|c|}{ LVH type } & \multirow[b]{2}{*}{ Total } & \multirow[b]{2}{*}{$\mathrm{p}$} \\
\hline & $\begin{array}{l}\text { Concentric } \\
(\mathrm{n}=93)\end{array}$ & $\begin{array}{l}\text { Eccentric } \\
(\mathrm{n}=49)\end{array}$ & $\begin{array}{l}\text { Asymmetric } \\
(\mathrm{n}=50)\end{array}$ & & \\
\hline Mild $(n=67)$ & $179 \pm 21$ & $176 \pm 20$ & $177 \pm 18$ & $178 \pm 21$ & \\
\hline Moderate ( $\mathrm{n}=105)$ & $186 \pm 27$ & $181 \pm 19$ & $172 \pm 13$ & $183 \pm 25$ & \\
\hline Severe $(\mathrm{n}=20)$ & $186 \pm 26$ & 200 & $179 \pm 22$ & $184 \pm 24$ & 0.220 \\
\hline Total & $184 \pm 25$ & $179 \pm 20$ & $175 \pm 17$ & $181 \pm 23$ & \\
\hline $\mathrm{p}$ & \multicolumn{4}{|l|}{0.177} & \\
\hline
\end{tabular}

$\mathrm{LVH}=$ left ventricular hypertrophy

tolic pressure was highest in cases of concentric LVH and lowest in cases of asymmetric LVH, but not significantly. The higher systolic pressure values in severe LVH degrees were not statistically significant either.

Diastolic blood pressure. There was no significant difference in diastolic blood pressure according to either type or degree of LVH.

Mean arterial pressure. Analysis of mean arterial pressure values showed no statistically significant difference according to LVH type or degree.

Pulse pressure. Pulse pressure was significantly higher in concentric LVH than in eccentric and asymmetric LVH, the values of which did not differ statisti- cally. It increased with LVH degree but not significantly (Table 4).

Correlation analysis among blood pressure components and left ventricular mass/relative wall thickness showed that there was no significant correlation between study variables $(\mathrm{r}=0.03$ for pulse pressure and LVM; and $\mathrm{r}=-0.03$ for pulse pressure and relative wall thickness).

\section{Analysis of therapy administered to different groups of patients}

Considering therapy, there was no significant difference according to the duration (ANOVA, $F=0.212$, 
Table 4. Pulse pressure according to type and degree of LVH

\begin{tabular}{|c|c|c|c|c|c|}
\hline \multirow[b]{2}{*}{ LVH degree } & \multicolumn{3}{|c|}{ LVH type } & \multirow[b]{2}{*}{ Total } & \multirow[b]{2}{*}{$\mathrm{p}$} \\
\hline & $\begin{array}{l}\text { Concentric } \\
(\mathrm{n}=93)\end{array}$ & $\begin{array}{l}\text { Eccentric } \\
(\mathrm{n}=49)\end{array}$ & $\begin{array}{l}\text { Asymmetric } \\
(\mathrm{n}=50)\end{array}$ & & \\
\hline Mild (n=67) & $80 \pm 16$ & $75 \pm 18$ & $78 \pm 14$ & $78 \pm 17$ & \\
\hline Moderate $(n=105)$ & $86 \pm 19$ & $74 \pm 19$ & $66 \pm 16$ & $81 \pm 20$ & 0217 \\
\hline Severe $(\mathrm{n}=20)$ & $91 \pm 19$ & 80 & $76 \pm 15$ & $84 \pm 18$ & 0.217 \\
\hline Total & $84 \pm 18$ & $75 \pm 18$ & $73 \pm 16$ & $80 \pm 18$ & \\
\hline $\mathrm{p}$ & \multicolumn{4}{|l|}{0.029} & \\
\hline
\end{tabular}

$\mathrm{LVH}=$ left ventricular hypertrophy

Table 5. Antibypertensive therapy used in study population

\begin{tabular}{|l|l|l|l|l|l|}
\hline \multirow{2}{*}{ Antihypertensives } & \multicolumn{3}{|c|}{ LVH type } & \multirow{2}{*}{ Total } & \multirow{2}{*}{ p } \\
\cline { 2 - 4 } & Concentric & Eccentric & Asymmetric & & \\
\hline ACE inhibitors & $85(70 \%)$ & $34(63 \%)$ & $14(82 \%)$ & $133(69 \%)$ & 0.296 \\
(ARBs) & $94(78 \%)$ & $39(72 \%)$ & $11(65 \%)$ & $144(75 \%)$ & 0.438 \\
Calcium antagonists & $60(50 \%)$ & $26(48 \%)$ & $9(53 \%)$ & $95(49 \%)$ & 0.941 \\
Beta blockers & $55(46 \%)$ & $24(44 \%)$ & $6(35 \%)$ & $85(44 \%)$ & 0.732 \\
Diuretics & &
\end{tabular}

$\mathrm{LVH}=$ left ventricular hypertrophy; $\mathrm{ACE}=$ angiotensin-converting enzyme; $\mathrm{ARB}=$ angiotensin receptor blocker

$\mathrm{p}=0.858)$ or type of medication between the LVHtype/degree groups. Treatment with antihypertensive therapy was also equally distributed (Pearson $\chi^{2}$-test) (Table 5). Patients were using two or more drugs prior to the study.

\section{Discussion}

\section{Echocardiographic measurements}

Echocardiographic measurements confirmed anthropologic differences between the sexes; male subjects had greater heart cavities and LVM. Upon LVM indexing according to body surface area (LVMI), these differences between sexes disappeared. Twenty-six percent of men and $38 \%$ of women were obese. LVM adjustment for height ${ }^{2.7}$ yielded significantly higher values in women. The results confirmed the influence of obesity on LVM. However, this should not affect the objective of this study (i.e. which component of arterial pressure has the greatest impact on LVH modeling). The mean LVMI (and LVM/ht $t^{2.7}$ index) values for the whole group and for both sexes were far above the normal values. This confirmed an accurate patient selection and relevance of further analyses.

\section{Blood pressure measurement}

Blood pressure measurement within a period of several consecutive days is a better indicator of blood pressure variability than 24 -hour ambulatory measurement. Systolic blood pressure of our patients slightly increased with LVH degree (but not enough to be statistically significant), and it was significantly higher in female than in male subjects. It would be better to interpret the first result in a reverse manner, i.e. that the LVH degree proportionally increased with systolic blood pressure. It is possible that statistical significance was not achieved because most patients were treated before the study, and thus the LVH degree was lower than it would have been otherwise. Nevertheless, even such a mild correlation supported the expected. Short duration of hypertension listed in Table 1 means that data were obtained from patient history (which may not be true). Despite therapy, hypertension was not well controlled in some patients. Libhaber et al. found arterial stiffness to be associated with the LVMI and left ventricle wall thickness independently of conventional or ambulatory blood pressure and additional confounders in a never-treated population sample of 
women, but not in $\operatorname{men}^{19}$. In the study by Matsui et al., morning hypertension was a strong determinant of concentric $\mathrm{LVH}^{20}$.

\section{Systolic blood pressure}

Systolic blood pressure did not correlate with LVH type, meaning that the myocardial remodeling type in hypertonic patients does not depend on the pressure value, but rather on other factors. These are probably the mechanisms of gene regulation and level of expression, which determine the parallel or serial arrangement and replication of sarcomeres and protein synthesis via second messengers. Some authors claim that the volume overload causes asymmetric $\mathrm{LVH}^{21}$, and that dilated LVH occurs during the late phase of the hypertensive disease ${ }^{22}$.

\section{Diastolic blood pressure and mean pressure}

It seems that diastolic blood pressure has no effect on the LVM increase ${ }^{23,24}$, which also holds true for the mean pressure.

\section{Pulse pressure}

Slight increase of pulse pressure with LVH degree was probably mediated through systolic pressure. It was significantly highest in concentric LVH cases, in comparison to eccentric and asymmetric LVH. The fact that the same results were not obtained for systolic pressure suggests that pulse pressure has a greater effect on the geometry formation of the left ventricle. Pulse pressure in the aorta of $>85 \mathrm{~mm} \mathrm{Hg}$ can help identify a hypertonic subject with concentric LVH. An independent inverse relation between aortic size and pulse pressure in older hypertensive subjects was demonstrated ${ }^{25}$. Pulse pressure is considered to be an independent predicting factor of cardiovascular mortality, as well as all-cause mortality ${ }^{26-28}$. Increased pulse pressure correlated with LVMI in a large group of patients suffering from non-treated essential hypertension ${ }^{29}$. Similar results were obtained by other authors ${ }^{30}$. Increased pulse pressure implied a more severe LVH, and it was a risk factor for concentric $\mathrm{LVH}$ in young men ${ }^{23}$. Unlike the approach where the authors observed the effect of pulse pressure on LVH where pulse pressure was a risk factor for the concentric type, we directly compared the effect of each component of blood pressure in the LVH pattern. We found a slight upward trend in systolic blood pressure and pulse pressure with LVH degree, but only the pulse pressure increase was significantly associated with the concentric LVH type. From the pathophysiological perspective, it seems that in most cases higher pulsatile load not only affects the increased LVM but also the formation of concentric LVH. The results of a previous study ${ }^{23}$ were obtained in young men, whereas our results are related to the elderly population of both sexes.

\section{Isolated systolic hypertension}

We analyzed a subgroup of patients with isolated systolic hypertension. Their number was small $(n=36$, 19\%). Analysis showed that there was no correlation between particular types of LVH and individual components of blood pressure. This could be explained by a small number of subjects distributed across the groups. Therefore, isolated systolic hypertension did not affect our result, or could have influenced it only in terms of obtaining a negative result.

\section{Medication}

In order to see whether therapy affects the results of the observation, we analyzed the medications applied and duration of treatment, and we concluded that there were no treatment differences among the groups observed. Medication could have affected the correlation between blood pressure and left ventricular geometry in a way to reduce the degree of $\mathrm{LVH}$, but it could not (as known until now) affect the type of LVH. We assumed that the drugs decreased systolic blood pressure and diastolic blood pressure in the same proportion.

Study limitations. The limitation of the study was the relatively small number of patients. Considering the strict inclusion criteria, it was a challenge to recruit a larger group of patients with isolated septal hypertrophy. In order to obtain a comparable number of patients in each of the three groups, a smaller number of patients with concentric LVH was included than found during testing. This resulted in a relatively small number of subjects per group. Recruiting lasted for as long as 7 years.

With regard to the type of the study, we could not conclude that pulse pressure caused concentric LVH, although it was significantly associated with this type of LVH. 


\section{Conclusion}

Pulse pressure is significantly higher in concentric $\mathrm{LVH}$ cases. It appears to be the major factor influencing the pattern of left ventricular remodeling, particularly in the concentric type.

\section{References}

1. Katholi RE, Couri DM. Left ventricular hypertrophy: major risk factor in patients with hypertension: update and practical clinical applications. Int J Hypertens. 2011;2011:4953, http:// dx.doi.org/10.4061/2011/495349

2. Palmieri V, Devereux RB, Hollywood J, Bella JN, Liu JE, Lee ET, et al. Association of pulse pressure with cardiovascular outcome is independent of left ventricular hypertrophy and systolic dysfunction: the Strong Heart Study. Am J Hypertens. 2006;19:601-7.

https://doi.org/10.1016/j.amjhyper.2005.12.009

3. Laurent S. Predictors of cardiovascular mortality and morbidity in hypertension. Curr Med Res Opin. 2005;21 Suppl 5:7-11, https://doi.org/10.1185/030079905X56420

4. Assmann G, Cullen P, Evers T, Petzinna D, Schulte H. Importance of arterial pulse pressure as a predictor of coronary heart disease risk in PROCAM. Eur Heart J. 2005;26:2120-6, https://doi.org/10.1093/eurheartj/ehi467

5. Bangalore S, Messerli FH, Franklin SS, Mancia G, Champion A, Pepine CJ. Pulse pressure and risk of cardiovascular outcomes in patients with hypertension and coronary artery disease: an International Verapamil SR-trandolapril Study (INVEST) analysis. Eur Heart J. 2009;30:1395-401, https://doi. org/10.1093/eurheartj/ehp109

6. Zakopoulos NA, Ikonomidis I, Vemmos KN, Manios E, Spiliopoulou I, Tsivgoulis G, et al. Twenty-four-hour heart rate and blood pressure are additive markers of left ventricular mass in hypertensive subjects. Am J Hypertens. 2006;19:170-7, https://doi.org/10.1016/j.amjhyper.2005.06.033

7. Cernes R, Peer M, Boaz M, Harpaz D, Matas Z, Shargorodsky M. Relation of arterial properties to left ventricular hypertrophy in hypertensive adults: focus on gender-related differences. Angiology. 2010;61:510-5, https://doi.org/10.1177/0003319709355800

8. Malone AF, Reddan DN. Pulse pressure. Why is it important? Perit Dial Int. 2010;30:265-8, https://doi.org/10.3747/pdi.2010.00002

9. Libhaber EN, Norton GR, Libhaber CD, Woodiwiss AJ, Candy GP, Essop MR, et al. Prevalence of residual left ventricular structural changes after one year of antihypertensive treatment in patients of African descent: role of 24-hour pulse pressure. Cardiovasc J Afr. 2012;23:147-52, https://doi.org/10.5830/ CVJA-2012-001

10. Coutinho T, Pellikka PA, Bailey KR, Turner ST, Kullo IJ. Sex differences in the associations of hemodynamic load with left ventricular hypertrophy and concentric remodeling. Am J Hypertens. 2016;29:73-80, https://doi.org/10.1093/ajh/hpv071

11. ESH/ESC Guidelines for the management of arterial hypertension. J Hypertens. 2007;25:1105-87, https://doi.org/10.1097/HJH.0b013e3281fc975a

12. Verdecchia P, Schillaci G, Borgioni C, Ciucci A, Gattobigio R, Zampi, et al. Prognostic value of left ventricular mass and geometry in systemic hypertension with left ventricular hypertrophy. Am J Cardiol. 1996;78:197-202.

13. Koren MJ, Devereux RB, Casale PN, Savage DD, Laragh JH. Relation of left ventricular mass and geometry to morbidity and mortality in uncomplicated essential hypertension. Ann Intern Med. 1991;114:345-52, https://doi.org/10.7326/00034819-114-5-345

14. Schillaci G, Verdecchia P, Borgioni C, Ciucci A, Guerrieri M, Zampi I, et al. Improved electrocardiographic diagnosis of left ventricular hypertrophy. Am J Cardiol. 1994;74:714-9, https:// doi.org/10.1016/0002-9149(94)90316-6

15. Lang RM, Bierig M, Devereux RB, Flachskampf FA, Foster E, Pellikka PA, et al. American Society of Echocardiography's Nomenclature and Standards Committee; Task Force on Chamber Quantification; American College of Cardiology Echocardiography Committee American Heart Association; European Association of Echocardiography, European Society of Cardiology. Recommendations for chamber quantification. Eur J Echocardiogr. 2006;7:79-108, https://doi.org/10.1016/j. euje.2005.12.014

16. Devereux RB, Reichek N. Echocardiographic determination of left ventricular mass in man. Anatomic validation of the method. Circulation. 1977;55:613-8, https://doi.org/10.1161/01. CIR.55.4.613

17. Ferrara LA, Vaccaro O, Cardoni O, Laurenzi M, Mancini M, Zanchetti A. Indexation criteria of ventricular mass and predictive role of blood pressure and body composition. Am J Hypertens. 2005;18:1282-7, https://doi.org/10.1016/j.amjhyper.2005.05.020

18. Foppa M, Duncan BB, Rohde LE. Echocardiography based left ventricular mass estimation. How should we define hypertrophy? Cardiovasc Ultrasound. 2005;3:17, https://doi.org/10.1186/1476-7120-3-17

19. Libhaber E, Woodiwiss AJ, Libhaber C, Maseko M, Majane $\mathrm{OH}$, Makaula S, et al. Gender-specific brachial artery blood pressure-independent relationship between pulse wave velocity and left ventricular mass index in a group of African ancestry. J Hypertens. 2008;26:1619-28, https://doi.org/10.1097/HJH.0b013e328302ca27

20. Matsui Y, Eguchi K, Shibasaki S, Ishikawa J, Shimada K, Kario $\mathrm{K}$. Morning hypertension assessed by home monitoring is a strong predictor of concentric left ventricular hypertrophy in patients with untreated hypertension. J Clin Hypertens. 2010;12:776-83, https://doi.org/10.1111/j.1751-7176.2010.00350.x

21. Hennersdorf MG, Strauer BE. Hypertension and heart. Med Klin. 2006;22:Suppl 1:27-30. 
22. Alter P, Rupp H, Stoll F, Adams P, Figiel J, Klose KJ, et al. Increased end diastolic wall stress precedes left ventricular hypertrophy in dilative heart failure - use of the volume based wall stress index. Int J Cardiol. 2012;157:233-8, https://doi. org/10.1016/j.ijcard.2011.07.092

23. Toprak A, Reddy J, Chen W, Srinivasan S, Berenson G. Relation of pulse pressure and arterial stiffness to concentric left ventricular hypertrophy in young men (from the Bogalusa Heart Study). Am J Cardiol. 2009;103:978-84, https://doi. org/10.1016/j.amjcard.2008.12.011

24. Wang SX, Xue H, Zou YB, Sun K, Fu CY, Wang H, et al. Prevalence and risk factors for left ventricular hypertrophy and left ventricular geometric abnormality in the patients with hypertension among Han Chinese. Chin Med J. 2012;125:21-6.

25. Dart AM, Kingwell BA, Gatzka CD, Willson K, Liang YL, Berry KL, et al. Smaller aortic dimensions do not fully account for the greater pulse pressure in elderly female hypertensives. Hypertension. 2008;51:1129-34, https://doi.org/10.1161/HYPERTENSIONAHA.107.106310

26. Fyhrquist F, Dahlöf B, Devereux RB, Kjeldsen SE, Julius S, Beevers G, et al. LIFE Study Group. Pulse pressure and effects of losartan or atenolol in patients with hypertension and left ventricular hypertrophy. Hypertension. 2005;45:580-5, https:// doi.org/10.1161/01.HYP.0000161186.55933.6b

27. Zhao L, Song Y, Dong P, Li Z, Yang X, Wang S. Brachial pulse pressure and cardiovascular or all-cause mortality in the general population: a meta-analysis of prospective observational studies. J Clin Hypertens. 2014;16:678-85, https://doi.org/ 10.1111/jch. 12375

28. Thomas F, Blacher J, Benetos A, Safar ME, Pannier B. Cardiovascular risk as defined in the 2003 European blood pressure classification: the assessment of an additional predictive value of pulse pressure on mortality. J Hypertens. 2008;26:1072-7, https://doi.org/10.1097/HJH.0b013e3282fcc22b

29. Vyssoulis GP, Karpanou EA, Liakos CI, Kyvelou SM, Tzamou VE, Michaelides AP, et al. Cardiovascular risk factor(s) prevalence in Greek hypertensives. Effect of gender and age. J Hum Hypertens. 2012;26:443-51, https://doi.org/10.1038/jhh.2011.55

30. Kim YJ, Goh CW, Byun YS, Lee YH, Lee JB, Shin YO. Left ventricular hypertrophy, diastolic dysfunction, pulse pressure, and plasma ET-1 in marathon runners with exaggerated blood pressure response. Int Heart. 2013;54:82-7, https://doi.org/10.1536/ihj.54.82

Sažetak

\title{
UČINAK POJEDINIH SASTAVNICA KRVNOG TLAKA NA OBLIKE HIPERTROFIJE LIJEVE KLIJETKE
}

\begin{abstract}
J. Kunišek i L. Kunišek
Prema sadašnjim spoznajama utjecaj pojedinih sastavnica arterijskog tlaka na pojavu hipertrofije lijeve klijetke (HLK) je različit. Željeli smo ispitati koja pojedina sastavnica arterijskog tlaka ima najveći učinak na geometrijski tip/stupanj HLK. U istraživanje je bilo uključeno 192 bolesnika (87 muškaraca) u dobi od 43-80 godina (prosječne starosti 68 godina) s hipertenzijom i HLK. Bolesnike smo podijelili u tri skupine prema tipu hipertrofije (koncentrična, ekscentrična i asimetrična) i tri podskupine prema stupnju hipertrofije (blaga, umjerena i teška). Svakom boesniku je mjeren krvni tlak, učinjena je elektrokardiografija i ehokardiografija. U obzir je uzeta antihipertenzivna terapija i trajanje prethodnog liječenja. Tlak pulsa je bio značajno viši u bolesnika s koncentričnom HLK nego u onih s ekscentričnom i asimetričnom HLK $(\mathrm{p}=0,029)$, no bez statistički značajne razlike među ovim vrijednostima. Tlak pulsa je rastao sa stupnjem HLK (ne značajno, $\mathrm{p}=0,217$ ). Sistolički tlak se nije značajno razlikovao među ispitivanim skupinama $(\mathrm{p}=0,177)$. Zaključili smo da je tlak pulsa imao najveći učinak na geometriju lijeve klijetke, osobito na koncentrični tip.
\end{abstract}

Ključne riječi: Hipertrofija lijeve klijetke; Krvni tlak; Hipertenzija; Elektrokardiografija; Ehokardiografija 